Journal of Business Research, Volume 62, Issue 3, Advances in Brand Management, March 2009, Pages 379-389

\title{
Co-Creating Brands: Diagnosing and Designing the Relationship Experience
}

Adrian Payne

Kaj Storbacka

Pennie Frow

Simon Knox

Submission: June 2007

Revision: May 2008

Acceptance in the Journal of Business Research: May 2008

Send correspondence to Adrian Payne, University of New South Wales, NSW 2052, Australia, T. +61 0293853390 F. +61 0296631985 (email: a.payne@unsw.edu.au). Kaj Storbacka, Nyenrode Business University, Netherlands, Straatweg 25, P.O. Box 130, 3620 AC Breukelen, The Netherlands, T. +31 346 291; F.+31 346 264. (email: kstorbacka@nyenrode.nl). Pennie Frow, University of Sydney, NSW 2006, Australia, T. +61 029351 6523; F. +61 0293516732 (email: p.frow@econ.usyd.edu.au). Simon Knox, Cranfield School of Management, Cranfield University, Cranfield, Bedford, MK43 0AL, UK. T. +44 (0) 1234 751122; F. +44 (0) 1234751806 (email: s.knox@ cranfield.ac.uk).

Acknowledgements: We wish to thank Dr Oskar Korkman for his contribution to the research process, two anonymous reviewers and the Special Issue Co-editors for their helpful comments on earlier versions of this article. 


\begin{abstract}
The traditional goods-dominant logic of marketing is under challenge and leading researchers are now emphasizing the new service-dominant logic (Vargo and Lusch, 2004). One of the key foundational propositions of this logic is the customer as "always being a co-creator of value" where "the brand becomes the experience" (Prahalad, 2004). In this paper, the authors examine the concept of brand relationship experience in the context of co-creation and service-dominant logic and outline a conceptual model for designing and managing the customer experience. Case study research illustrates how this model helps in the design and management of the brand relationship experience for an innovative new product.
\end{abstract}

Keywords: co-creation, brand, experience, service-dominant logic; brand relationship experience 


\section{Co-Creating Brands: Diagnosing and Designing the Relationship Experience}

\section{Introduction}

For a decade or more, researchers have called for a paradigm shift in marketing. (e.g., Grönroos, 1997; Gummesson, 1997; Sheth, 1996). Academics around the world are realizing that marketing, which initially adopted the customer's perspective, ironically, has lost this focus (Ambler, 2004). Now an increasing amount of research is emerging, re-focusing attention on the customer perspective. In particular, Vargo and Lusch's (2004) recent award-winning paper develops a provocative and exciting basis for a new service-dominant logic in marketing which emphasizes this customer perspective. As Ballantyne and Varey (2006) note, Vargo and Lusch bring together a number of previously disparate marketing concepts and ideas in a way that represents a fundamental challenge to the presumptions of mainstream marketing theory and practice.

Inherent in the service-dominant logic perspective is a view that service is the common denominator in exchange, not some special form of exchange - i.e., what goods are not (Vargo and Lusch, 2004). In addition, a service-dominant logic of exchange is likely to be more integrative than a goods-dominant logic (Vargo and Morgan, 2005). Central to this perspective is their foundational proposition relating to co-creation that involves customer's active involvement and interaction with their supplier in every aspect, from product design to product consumption. However, amidst this increasing amount of research on service-dominant logic, remarkably little attention focuses on the brand. One exception is Prahalad's (2004) commentary on Vargo and Lusch's work when he proposes an experience-centered, co-creation perspective where the brand becomes the experience.

The aim of this paper is to develop a conceptual model for understanding co-creation of a brand through relationship experience design in business-to-consumer markets utilizing managerial insights 
and existing marketing theory. The authors structure the article as follows: first, they review the nature of service-dominant logic and co-creation. Second, they discuss the literature relating to co-creation, brands, brand relationships and the customer experience. Third, they explain the process of developing the conceptual model for co-creation. This process utilizes “interactive research" (Gummesson, 2002) and consists of three phases - pre-understanding, analysis and model development. Fourth, they explain the model and its key components. Fifth, they use case study research to illustrate the application of the model in a company-specific context. Finally, they discuss the contribution of the article together with managerial implications and future research opportunities.

\section{Service-Dominant Logic and Co-Creation}

From the 1980s, newer perspectives such as relationship marketing, quality management, market orientation, services marketing and brand relationships have challenged the dominant logic of marketing (Smit, Bronner and Tolboom, 2007). These newer frames of reference have also identified limitations in the traditional goods-dominant logic. A common theme in this body of work is that the dominant logic of marketing is shifting from the exchange of tangible goods to the exchange of intangibles such as skills, knowledge and processes.

From a goods-dominant logic perspective, suppliers produce products and customers buy them. With a service-dominant logic, customers engage in dialogue and interaction with their suppliers during product design, production, delivery and consumption. Researchers now often use the term co-creation (or co-production) to describe this customer-supplier dialogue and interaction. Service-dominant logic suggests that value starts with the supplier understanding customer value-creating processes and learning how to support customers' co-creation activities. Thus, the customer as "always being a co-creator of value" is a key foundational proposition of this logic (Vargo and Lusch, 2004). 
These developments provide an opportunity to look at branding and brands through the lens of cocreation and customer experiences. Given Prahalad's (2004) co-creation viewpoint where the brand becomes the experience, de Chernatony's (2006) contemporary experiential definition of a brand is especially relevant: "A brand can be regarded as a cluster of functional and emotional values, which promises a unique and welcome experience [emphasis added]". This article explores the nature of the brand as a relationship experience (the brand relationship experience). The authors use this term to represent a relationship-based view of the brand seen from the perspective of ongoing customer experiences - a perspective consistent with co-creation and service-dominant logic.

\section{Co-Creation and Brands}

Researchers such as Grönroos (2000), Prahalad and Ramaswamy (2000) and Vargo and Lusch (2004) argue that value is embedded in the co-creation process between the customer and the supplier, and where the customer shifts from being a passive audience to an active player. Prahalad (2004) proposes that value creation is embedded in personalized experiences: “... early experimenters are moving away from the old industry model that sees value as created from products and services to a new model where value is created by experiences". This research concurs with earlier work on experiential marketing (e.g., Holbrook and Hirschmann, 1982) which emphasizes emotions, contexts and symbolic aspects of experiences. Later work suggests that creating value is not so much about conventional advertising and branding, but focuses on building processes to support the customer experience (e.g., Pine and Gilmore, 1999).

Despite the substantial quantity of research on branding issues, this topic remains a fragmented and contextual concept (Jevons, 2007). Further, researchers in the brand management domain place surprisingly little emphasis on brand relationships, customer experience and co-creation. In the context 
of service-dominant logic, Arnould, Price and Malshe (2006) observe that branding and brand equity “seem ripe for revision". Leading researchers Keller and Lehmann (2006) recently reviewed research and future priorities in branding. They highlighted brand relationships and customer experience as two key areas requiring further development.

Some research is now starting to emphasize the building of brands and relationships around customers rather than company requirements (e.g., Dall'Olmo Riley and de Chernatony, 2000), and such work is moving brand researchers in the direction of a co-creation approach to the brand (e.g., Bello, de Chernatony and Shiu, 2007). However, in the area of service-dominant logic and co-creation, little work deals with brands and brand experiences. As Brodie, Glynn and Little (2006) observe, any reference to branding in the service literature is often indirect and that Vargo and Lusch (2004) only briefly mention the branding concept. Building on this introduction, the authors now review the relevant literature in the areas of brand relationships and customer experience.

\section{Brand Relationships, Customer Communities and Customer Experience}

Smit et al. (2007) argue that the brand relationship concept is an important research topic because of the potential advantages such as reduced marketing costs, ease of access to customers, improved acquisition of new customers, and improved customer retention and profitability. Despite this observation, the topic remains under-researched. Fournier (1998), in her review of relationship theory in the brand domain, points to a deficiency of relationship-based studies in consumer markets and especially those concerned with consumer products.

More recently, researchers have used the relationship perspective as the main theoretical lens for understanding consumer brand interactions (e.g., Swaminathan, Page and Gurhan-Canli, 2007). Several researchers also support the concept of customers having relationships with their brands (e.g., Fournier, 
1998; Muniz and O'Guinn, 2001; Rozanski, Baum and Wolfsen, 1999; Smit, Bronner and Tolboom, 2007). However, as Dowling (2002) and O’Malley and Tynan (2001) point out, the importance of the brand to the consumer does vary as some brands inherently may be better suited for building a relationship than others.

In this article, the authors adopt Aggarwal's (2004) view that consumers form relationships with brands that mirror their social relationships. He defines relationships as "a sequence of interactions between parties where the probable course of future interactions between them is significantly different from that of strangers" - thus "consumer interactions with brands can be characterized as relational". Aggarwal concludes that even though people's relationships with brands do not necessarily share the same richness and depth as their relationships with human partners, they can interact with brands as if they have a relationship with them.

Within the consumer research literature, there is evidence of an increasing focus on co-creation and topics related to this subject. Of particular interest is the nature of customer-to-customer interactions and the role of the customer as a co-creator. This work is discussed more generally within the research on consumer tribes or brand tribes, brand communities and user communities. Other specific terms used to describe these customer to customer interactions include: "Citizen Marketers" (McConnell and Huba, 2007) and "Wikinomics" (Tapscott and Williams, 2006).

Research interest in the concept of consumer tribes (e.g., Bennett, 1999; Cova, 1997; Cova and Cova, 2002; Cova, Kozinets and Shankar, 2007, Kozinets, 1999; Patterson, 1998), and brand communities (e.g., McAlexander, Schouten, and Koenig, 2002; Muniz and O'Guinn, 2001) has increased significantly in recent years. Brand identity is co-created with consumers and other stakeholders and this element of co-creation is especially apparent in consumer groups such as brand communities. Typically, these groups become active carriers of brand meaning, rather than followers of the company's idea of the 
constituion of their brand (e.g., Csaba and Bengtsson, 2006; McAlexander et al., 2002; Muniz and O’Guinn, 2001).

A further related area of research focuses on user communities, user innovation and user design. Researchers describe user communities as sub-cultures of consumption which involve consumers as innovators in the active creation of markets, alongside company development of new products (Goulding and Saren, 2007). This work includes literature on lead users in the business-to-business sector (e.g., Urban and Von Hippel, 1988; Von Hippel, 1986) and on-line product innovation by user groups (e.g., Füller, Jawecki and Mühlbhacher, 2007).

Several key points emerge from consideration of the research reviewed in this section. First, the relationship perspective is receiving more attention, including the notion of customers having some form of relationship with their brands. Second, attention is shifting from brand producers to an understanding of how consumers' responses create brand meaning and how branding works (e.g., Schroeder and Salzer-Mörling, 2006). Third, researchers are now recognizing the importance of customer-to-customer interactions and the role brand communities can play in co-creation. Fourth, researchers are acknowledging that the customer can have an important place in co-creating innovative ideas for product development and becoming more closely involved with the brand. When the customer becomes a codesigner of a product, potential exists to enhance their emotional connection with a brand (e.g., Demirbilek and Sener, 2003). Finally, Holbrook (2006a; 2006b; 2007a; 2007b), in assessing ten recent managerial contributions in the area of experience management, concludes that much of this work has a general lack of conceptual foundation and empirical direction.

Whilst the research outlined above adds considerable insight into a number of specific aspects of marketing relationships, customer experience and brands, the authors conclude that researchers have given little attention to developing conceptual frameworks and methodologies that focus on managing 
and designing customer's brand experiences from a managerial perspective. Fournier (1998) supports this view and concludes that no studies “...have yet offered a comprehensive relationship-oriented view of consumer-brand interactions - one that starts with basic relationship principles and builds an integrative framework to explain and explore the form and dynamics of those interactions". These considerations led the authors to develop the following research question: How can a conceptual model, that integrates the concepts of co-creation and branding, be developed for diagnosing and designing customer relationship experiences? This research question provides the motivation for the current research.

\section{The Model Development Process}

The research reported here is part of an investigation into co-creation involving the development of a conceptual model for co-creation purposes that the authors extend to encompass contemporary thinking on branding. Figure 1 shows an overview of the model development process. The research utilized “interactive research" (Gummesson, 2002), where "interactions with groups of managers play a crucial role in research generation and concept testing". The process consisted of the following three phases pre-understanding, analysis and model development. Each phase included a full-day research workshop with senior level executive vice-presidents and their direct reports, drawn from eighteen organizations. Whilst Vargo and Lusch (2008) note that service-dominant logic has the potential to unify and simplify apparently disparate thoughts between consumer and industrial marketing, the primary focus of this current research interest is on business-to-consumer relationships. Sixteen of the eighteen companies were involved in business-to-consumer relationships. Two companies had business-to-business relationships. These were included in the sample as the researchers were interested in learning whether 
data from the business-to-business sector might provide further insight in understanding value cocreation within the business-to-consumer sector.

\section{FIGURE 1 HERE}

Nine of these organizations are substantial international companies; the remaining nine are major companies operating on a regional basis or are nationally based firms. The organizations involved in this study are service providers (travel, hospitality, energy, retail, software), financial services providers (financing and insurance), fulfillment organizations (logistics companies), media companies (newspaper and television) internet and mobile service access (telecommunication operators), and mobile device and network providers (mobile phone companies). The organizations participated in the research process as they have a keen interest in exploring new ways to co-create value and build meaningful experiences for their customers.

During the pre-understanding phase, shown in Figure 1, the authors developed an initial framework for managing the co-creation of value based on the literature on value, value chains, co-creation, servicedominant logic, relationship marketing, consumer behavior and branding. To refine this initial framework, which reflects the centrality of processes in co-creation (e.g. Vargo and Lusch, 2004; Webster, 2002), the authors discussed the framework during interviews with two senior level executives from each of the eighteen companies. Following this initial work, they then held the first interaction research workshop. This workshop was directed at identifying co-creation insights within customersupplier relationships. After a detailed briefing of the executives, the authors divided the managers into groups of between four and six people and asked them to describe the key components of value cocreation within customer-supplier relationships. During the workshop, the researchers recorded these components on white boards, and the managers then progressively refined their initial conceptualizations. 
During the analysis phase, the authors analyzed the output of the first workshop with reference to a further literature review, data from the interviews and other data collected from the companies during the first phase of the research. Based on this analysis, they developed a preliminary version of the conceptual model, which was refined further during the second interactive research workshop. This workshop adopted a similar process as the first one and focused on evaluating and critiquing the emerging framework and its components.

During the model development phase, the authors undertook a synthesis of the output from the second workshop where participating companies identified key themes and best practices. The authors extended their literature review as they developed the model and identified further components. In the third interaction research workshop, the authors presented this revised model and asked participants to consider this model in the context of their own companies. Many of the organizations had utilized some of the model components in the time between the second and third workshops and applied them in their own company's development work. This final workshop provided a further opportunity to refine the model. In the next section, the authors discuss the model for co-creating the brand relationship experience and the key processes involved.

\section{The Model: Key Components and Processes}

The importance of processes is widely acknowledged in both the literature on marketing strategy and customer management (e.g., Srivastava, Shervani and Fahey, 1999; Webster, 2002) and on servicedominant logic and co-creation (e.g., Prahalad and Ramaswamy, 2004; Vargo and Lusch, 2004;). In particular, Vargo and Lusch (2004) suggest that researchers can regard marketing as a set of processes and resources with which the company seeks to create value propositions. These processes include procedures, tasks, activities, mechanisms, and interactions that collectively support the co-creation of 
value. This focus on processes is a key feature of the model. The academic literature, earlier research and later field-based work confirmed the need for a practical process-based co-creation model.

The model outlined in Figure 2 extends an earlier, more general co-creation framework to consider brand and experience-related issues together with recent work on brand synthesis and brand knowledge (Keller, 2003; Payne, Storbacka and Frow, 2008). The model consists of four main components: the customer's value-creating process - concerned with co-creating and experiencing a brand relationship; the supplier's value-creating process - concerned with designing and co-creating a brand relationship experience; encounters where (usually) ongoing interactions are involved in creating these experiences; and, the impact of additional sources of brand knowledge (Keller, 2003).

\section{FIGURE 2 HERE}

Several streams of theoretical work are reflected in the model including: work by: Grönroos (2000), Holbrook and Hirschmann (1982), Korkman (2006), Normann (2001), Normann and Ramirez (1993), Oliver (1999), Prahalad and Ramaswamy (2000), Storbacka and Lehtinen (2001) and Vargo and Lusch (2004) - for the customer value-creating processes; Normann (2001), Pine (1993) and Sawhney (2006), Storbacka and Lehtinen (2001) - for the supplier value-creating processes; Ballantyne and Varey (2006), Gremler (2004), Grönroos (2006) and Vargo and Lusch (2004) - for encounters; and, Keller (2003) - for the additional or secondary sources of brand knowledge. The authors now examine each of these four components in more detail:

\section{The customer value-creating process}

The customer's processes represent a series of activities through which the customer aims to achieve a particular purpose. These activities collectively contribute to the brand relationship experience. Figure 2 shows the key components of the customer value co-creating processes. 
The brand relationship experience considers two perspectives of consumer behavior, the informationprocessing perspective and the experiential perspective including the role of consumer communities and user innovation.

The academic literature documents comprehensively the traditional information-processing perspective, typically referred to as the C-A-B (cognition, affect and behavior) approach (e.g., Thompson and Fine, 1999). This approach views the customer as primarily involved in goal-directed activities including searching, confirmation, evaluating alternative options and deciding whether, or not, to buy a particular product. However, some researchers criticize this approach for being too restrictive and failing to account for the experiential nature of consumer behavior (e.g., Holbrook and Hirschmann, 1982). To counter this problem, pioneering consumer researchers propose the experiential or "hedonic" perspective, where experiential consumption includes the flow of fantasies, feelings and fun in which processes are more sub-conscious and private in nature (Holbrook and Hirschmann, 1982).

This experiential perspective offers especially significant opportunities for co-creation. However, elements of information processing such as searching for information, evaluating alternatives and generating choice sets, can lead to more knowledgeable and better informed customers. The intention is to provide customers with knowledge and facts, and for them to make decisions, which encourages customer involvement in co-creation behaviors. Thus, this C-A-B perspective can provide support for subsequent important co-creative processes such as knowledge sharing and communication. In sum, rather than adopting an extreme position on either perspective, the model incorporates a consideration of both perspectives.

Experiences are especially important as they can encourage the customer to participate increasingly in the process of co-creation. Normal, day-to-day service experience and practices (e.g., Edvardsson, Enquist and Johnston, 2005; Korkman, 2006) as well as peak experiences (e.g., Pine and Gilmore, 1999) 
both lead to customer learning, which involves a combination of experiential encounters over the length of the relationship. Two perspectives of customer learning are useful. First, using a sense-making, cognitive perspective, and second, identifying the experiences embedded in the co-creation process.

The literature review highlights the importance of customer communities, customer-to-customer interactions and the role that customers can play in product design and innovation. The customer has the opportunity to participate actively in the co-creation process through their innovation and product design (e.g., Füller, Jawecki and Mühlbacher, 2007). In particular, the development of the internet provides substantial opportunities for online involvement of consumers in product design (e.g., Kamali and Loker, 2002).

Over time, the customer's ability to co-create is developed, reinforced or altered because of their ongoing sequence of experiences. External or supplier-initiated factors can cause customers to alter their behavior and existing practices in adopting new processes - the model refers to these processes as customer learning. For example, the processes that retail banks use to help customers understand the value of switching from branch-based banking to on-line banking illustrate this form of learning. While the benefits of using on-line banking may appear obvious, a cognitive approach based on explanations and directions is unlikely to work satisfactorily by itself. Only by engaging the customer in a co-creation experience, and by learning from this experience, is the customer likely to change his or her routinized banking behavior. Suppliers who understand the nature of customer learning can develop processes to support and improve a customer's capability to co-create.

\section{The supplier value-creating process}

The supplier process should start with a consideration of co-creation opportunities and alternatives. Researchers such as Bendapudi and Leone (2003) distinguish between different forms of co-creation including: the emotional engagement of customers (e.g., through advertising and promotional activities); 
self-service; engaging the customer in an experience (e.g., white-water rafting); using processes to allow the customer to solve their own problems (e.g., self-diagnosis of computer fault on a website); and where the customer actively engages with the supplier to help design a product, (e.g., Boeing actively encourages the involvement of their airline customers in aircraft design). Brand relationship experience design involves the selection, planning and implementation of value-adding activities and experiences for the customer. Service-dominant logic suggests starting with the customers' value creation processes and identifying which of those processes the supplier has the ability and wishes to support.

Techniques for understanding the total consumption system of the customer, such as service blueprinting (e.g., Kingman-Brundage, 1989), provide the opportunity to add value to the customer's brand experiences. Service blueprints consider the entire design of a service operation as if through the customers' eyes (Brown, Fisk and Bitner, 1994). However, this blueprinting technique can often ignore the customer viewpoint (Brooks and Lings, 1996). In undertaking blueprinting, companies should not compromise understanding of customer experiences in service encounters and suppliers should assess such experiences from a managerial, rather than a customer perspective (Pires, Stanton and Stanton, 2004). The supplier's challenge is to ensure the service design process produces customer experiences that lead to customer satisfaction, are operationally efficient and facilitate desired outcomes. The supplier needs to take the voice of the customer fully into account, as customer input is critical to ensuring richer experiences. Pires, Stanton and Stanton (2004) illustrate how suppliers can incorporate the role of customer experiences into the development of service blueprints.

Service-dominant logic distinguishes operand and operant resources. Vargo and Lusch (2004) define operand resources as those on which an operation or act is performed to produce an effect; and operant resources as ones, such as embedded knowledge and skills (e.g. technology), employed to act on operand resources. These operant resources can manifest themselves as core competences, capabilities 
and organizational processes, which are vital to the co-creation of value. Developing knowledge management systems that enable an understanding of customer co-creation opportunities is important and requires more information from customers than the usual managerial metrics deployed, such as measures of customer satisfaction, retention rates and customer loyalty. Suppliers need to incorporate a full understanding of the customer's brand experience and how customers engage with the supplier's products and services over time. In particular, the supplier has the opportunity to encourage the formation of customer communities and motivate user-innovation and design.

\section{Encounters}

The encounters in Figure 2 represent a series of interactions and transactions occurring during the relationship between the customer and supplier. The encounters can occur either on the initiative of the company (e.g., through an outbound telephone call), or on the initiative of the customer (e.g., via an enquiry or complaint); or on the initiative of both (e.g., attending a car auction). Figure 2 represents these encounters through two-way arrows that link supply processes to those of the customer. The arrows are deliberately two-way, emphasizing a key element of service-dominant logic - increasing cocreation and dialogue within the relationship (Ballantyne and Varey, 2006).

The encounters represent processes where both parties are interacting and mutually co-creating experiences. The appropriate form and mix of these co-creative processes will be highly context specific, and will vary based on the nature and length of the relationship. Co-creation involves encounters that influence the customer's ability, willingness and opportunities to co-create with the supplier. Two aspects facilitate the co-creation of a brand: communicating the brand; and acting upon the brand. Either the customer or the supplier, or both (and potentially other stakeholders) may be involved. 
Certain co-creative encounter processes are generic whilst others are dependent on the nature of the supplier and the supplier's relationship with the customer base. The encounters can support co-creation from a cognition point of view aiming at sense making (e.g. "why should I involve myself in co-creation and what is the meaning of this brand to me?") and communication of behavioral scripts, customer promises, value-explaining messages, outcomes, references and testimonials. Typical examples include knowledge sharing (e.g., exchanging user experiences, or sharing experiences of competitive suppliers), and creating expertise (e.g., providing and using on-line tutorials for any type of service).

Co-creation may also be emotion supporting, aiming at either influencing or engaging the customer (e.g., how deeply should I be involved with this brand?) with themes, metaphors, stories, analogies, design elements, new options, surprise or offering forms of customer recognition. Typical examples of co-creation processes include emotional engagement (e.g., becoming an active member in suppliermanaged clubs, becoming an advocate for the brand), or positive surprise (e.g., amazing the customer by continuously offering new and exciting ways to experience the service).

Finally, the encounters may be action-supporting, enabling the customer to engage in activities such as trials, knowledge sharing, self-service activities, and usage of the product. Examples of such engagement are quality management (e.g., creating user feedback systems and responding to the feedback), and enabling efficient self-service (e.g., creating easy to use interfaces with mobile devices and/or PC's). Later in this article, the case study illustrates a number of the above examples.

Co-creation opportunities represent strategic options for suppliers to create increased brand meaning for customers. These opportunities are based on the context of the individual organization being studied (Payne et al., 2008), and include: technological developments opportunities (e.g., opportunities for customers to directly engage with the supplier or other customers online); changes in industry logics opportunities (e.g., the emergence of new competitors may create more excitement and engagement by 
customers); and changes in customer preferences and lifestyles opportunities (e.g., environmental concerns are creating incentives for customers to co-create in order to save energy).

Managing encounters to co-create brands also includes consideration of the content and experiences that are appropriate for different relationship phases. These phases include acquisition, stabilization and enhancement. In the beginning of a relationship, there is a greater need to secure the customer's expertise enabling systematic co-creation. The experienced customer can however, engage more holistically in co-creation. Identifying and mapping encounters for each of these phases can help understand how customers and suppliers each experience their relationship. Managing encounters involves setting relationship objectives for both customer and supplier, and determining whether such encounters are achieving these objectives. The case study introduced later helps explain these planning and implementation steps.

Suppliers can develop successful co-creation initiatives based on customer encounters. They can use these encounters to educate their customers on how to engage in co-creation behaviors. A good example is IKEA, whose business model is highly dependent on customers' co-creation activities. IKEA's marketing communications strive to teach the customer the wisdom of value co-creation: "It's easier to save money when we all lend a hand.” The company's promotional material and catalog explain in detail how a customer can get the best value from IKEA and its products. Whilst engaging with the brand, IKEA's customers participate in a number of co-production and co-servicing activities including transportation and assembly.

\section{Additional sources of brand knowledge}

The final component of the model (Figure 2) represents the additional or secondary sources of brand knowledge that can affect brand perceptions. Keller (2003) observes any potential encounter with a brand, irrespective of whether or not the encounter is supplier-initiated, "has the opportunity to change 
the mental representation of the brand and the kinds of information that can appear in the customer memory". He also points out that with increasingly competitive marketplaces, suppliers must take into account these additional sources of brand knowledge that relate to a range of other stakeholder influences. These include: customer-to-customer interactions (brand communities and user innovation); employee-to-customer interactions; other stakeholders (such as intermediaries and influencers); third party endorsement and events; places (including channels and origination); and other brands (including alliances and extensions).

Many of these sources of brand knowledge may be present in encounters and, in themselves, provoke co-creation processes. For example, customers may be encouraged in active co-creation by becoming engaged in brand communities, where customers together invent new uses for goods or services. The spread of SMS messaging (first aimed at business users) amongst teenagers is a good example of customers inventing a new use for a service.

Inclusion of such sources in the model emphasizes the need to consider these broader external influences on the encounters in the supplier-customer interface. Many researchers (e.g., Balmer, 2006; Balmer and Gray, 2003; Dall'Olmo Riley et al., 2000; de Chernatony and Harris, 2000; and Shultz and Hatch, 2006) endorse the importance of considering this wider range of stakeholders in the context of brands and branding.

\section{Case Study Research: Co-creating a Brand through Relationship Experience Design}

Many conceptual models developed in the marketing and management academic literature do not attempt to illustrate how managers can use such models in a company-specific situation. The authors address this limitation in the second phase of this study, which involves case study research. This research illustrates the application of the co-creation model in designing and planning a relationship 
experience that systematically utilizes co-creation opportunities. In identifying a suitable business-toconsumer company for the case study, the researchers developed three criteria. First, to identify a company with an existing co-creation initiative that capitalizes on at least two of the value co-creation opportunities proposed by Payne et al. (2008) - technological developments, changes in industry logics and changes in customer preferences and lifestyles. Second, to select a case study that utilized new technological applications from a novel industry setting - given the marketing literature is replete with examples from industries such as financial services, retailing and hospitality. Finally, given the recent emphasis on branding issues relating to sustainability and social responsibility (e.g., Blomqvist and Posmer, 2004; Charter, Peattie, Ottman and Polonsky, 2002; Knox and Maklan, 2004; Van Heel, Elkington and Fennel, 2001), to develop a case study that relates to a sustainable product innovation. The authors compiled a shortlist of alternatives case studies and, after an initial investigation of each using the above selection criteria, they selected a car-sharing club for case study development.

\section{The City Car Club}

Car sharing clubs are popular throughout Europe and North America. They offer the means of car transportation, yet overcome the high cost of keeping a car in the city and allow drivers to behave in an environmentally responsible way. Launched in Helsinki, Finland, in 2000, the City Car Club (CCC) offers members an alternative to owning a car. Finland has a reputation for championing 'Green' issues and the Club has strong emotive appeal to environmentally concerned individuals who are attracted to shared car ownership and usage. On joining the Club, a member has access to a self-selected car at any time and in convenient locations. In addition, CCC offers significant financial advantages, as the rental service only charges for usage and duration. $\mathrm{CCC}$ is attractive as a case study because this company capitalizes on at least two of the generic co-creation opportunities outlined above: changing customer preferences; and, harnessing technological developments. 


\section{Methodology}

The main objective of the CCC case is to illustrate how the co-creation model in Figure 2 can be utilized for designing, planning and managing a relationship experience that offers enhanced co-creation opportunities. Thus, the data generation aimed at providing a rich description of how CCC management developed its service and how its customers engage in co-creation. This data generation involved the collection of both primary and secondary data and followed a purposive sampling approach (e.g. Eisenhardt, 1989; Wallendorf and Belk, 1989), with each respondent group or artifact selected on the basis of previous responses.

Data was gathered from the following sources: three interviews with senior management of the CCC, five interviews with active customers, a customer survey, a focus group of potential customers, customer blogs, company data, the CCC website, third party blogs and magazine articles about CCC and car clubs in general.

Using these sources, the reserachers progressively interpreted the data to adapt the model in Figure 2, providing deeper insights and closer represenation of the CCC brand relationship experience. Initially, the researchers coded specific elements relating particularly to the planning and encounter processes. The subsequent analysis focused on identifying relevant forms of co-creation opportunities, from early emotional engagement with the brand to repeat usage of the service and customer feedback systems. Data was then coded for each phase from the perspective of both the customer and the supplier. This data was then related to the objectives for the three key relationship phases of acquisition, stabilization and enhancement (see Figure 3). The authors then used the data to map processes, including the creative use of channels to enhance encounters (see Figure 4). Analysis followed the constant comparative method (e.g., Glaser and Strauss, 1967), whereby new data was compared to previous interpretations. 
The authors then reviewed the findings and made decisions about further data required to give a full description of the brand relationship experience.

For example, secondary data was initially used to understand the supplier processes and identify possible points of value co-creation. The authors then investigated these points further and collected primary data to give deeper insight into these relationship encounters. The research process was iterative, therefore, with analysis informing the selection of additional data required to give a full picture of the processes involved in co-creation. The authors continued the process until they were confident that they had accurately described the creation of a brand relationship experience. Senior management at the City Car Club verified, or "member checked", the final version of the model. The case study discussion on relationship experience design that follows is structured around three components outlined in Figure 2 - identifying opportunities for co-creation, planning and implementation.

\section{Co-creation opportunities}

Many forms of co-creation exist (e.g., Bendapudi and Leone, 2003) and this case study illustrates many of them, including the emotional engagement of the customer (e.g., appeal to environmental concerns); self-service (e.g., customer accessing the service when required); engaging the customer in the experience (e.g., the 'fun' element on accessing the car); and the use of systems to provide expertise for the customer (e.g., on-line tutorial to understand the rental system and experience).

Co-creation opportunities are apparent throughout the whole of CCC's relationship with its members. The business proposition is emotionally appealing to environmentally-conscious customers; the Club and its members can together impact environmental pollution by reducing car ownership and using environmentally friendly cars. Car-sharing has the potential to replace five to six private cars and research suggests that former car owners reduce their energy consumption for transport by some $50 \%$ when they join a car-sharing scheme (Loose, Mohr and Nobis, 2006). 
CCC uses technology creatively, providing several opportunities for co-creation. For instance, the customer can use their mobile phones to book a car, access the vehicle, complete the rental and pay for car usage. Much of the rental process is self-serve, a feature that reduces cost and adds to the convenience of the service. At the beginning of a rental period, the customer unlocks the vehicle by calling a service number followed by a unique customer pin and the registration number. At the end of the rental, the same number locks the doors and initiates data transfer from the car to the CCC back office systems. These systems accurately record the rental duration, distance travelled and location of the car. The customer's account is automatically debited, eliminating unnecessary administration by either customer or CCC. Additional opportunities exist for further enhancing the value co-creation opportunities by using telematics technology for security and information services, in-vehicle safety and remote vehicle diagonistics.

\section{Planning and developing objectives}

Planning and developing objectives relating to customer management forms an important initial part in designing the relationship experience. Planning for co-creation commences with an understanding of customer processes and how they may vary across different market segments. Successful implementation of plans require cross-functional alignment between the organizational functions involved in creating and delivering brand experience throughout the relationship phases of customer acquisition, stabilization and further development. Setting objectives for both customer and supplier learning at each of the phases and evaluating whether the current set of encounters are achieving these aims can build superior relationship experiences. Figure 3 outlines a set of objectives for CCC itself and the Club members.

FIGURE 3 HERE 
The aim of planning is to identify and design the various activities involved in building the relationship experience. For example, during the acquisition phase, an important issue for CCC is identifying how to appeal to potential members. Conveying the functional and emotional benefits of Club membership, such as the environmental and cost advantages, helps create this appeal. CCC has identified triggers for changing the behavior of prospective members by switching car owners to car sharing. Promotional messages may focus on creating meanings such as: "Using car sharing you can make a difference in reducing pollution, energy consumption, traffic noise and road accidents"; or, "Car sharing means that you do not have to worry about car insurance payments, car use taxes, maintenance vehicle outlay and value depreciation costs, changing tyres and oil, washing the car inside and out, annual roadworthiness checks, obtaining and paying for private parking space, etc.". In addition to appealing to prospective members, processes for joining CCC need to work efficiently. The process of becoming a CCC member is efficient, with easy-to-use systems that accurately collect customer data by an on-line application process.

During the stabilization phase, both CCC and member interact to learn how best to develop the relationship. For example, at the start of the first transaction, the Club provides a short tutorial on the Car Club rental process. This tutorial helps the customer understand how to gain the maximum value out of the membership, whilst reducing the number of service problems the company may need to resolve. A key aspect of the Club's use of the Internet application is that users are given control, choice and engagement with the service, helping them to willingly participate in co-creating value. For example, the booking system is simple and clear so customers can easily reserve their chosen vehicle at a designated time and place.

At the enhancement phase, CCC seeks to provide brand enhancement and further opportunities for co-creation. CCC collects customer information and uses this data to provide additional benefits for 
members. Long term members have the option of upgrading to a Silver Membership with reduced rates and car upgrades. Also, CCC partners with a hospitality company focusing on leisure destinations, in order to offer accommodation and car packages at attractive destinations.

\section{Implementation}

Having defined objectives for each of the relationship phases (customer acquisition, stabilization, and enhancement), the next step involves identifying the sequential encounters within each phase to determine how experiences can best be co-created. This step requires an understanding of what kinds of encounters best support customer learning and enables customers to play an active role in co-creation and achieve the desired objectives. Also, this step requires a consideration of the optimum use of channels which involves evaluating the costs of different channels and identifying how they can best be used to achieve customer and company objectives. Figure 4 illustrates a simple mapping process for CCC.

\section{FIGURE 4 HERE}

The encounter process identifies the interactions and transactions occurring between the customer and supplier determining how they can enhance value co-creation. As suggested earlier, there are several possible approaches to the mapping process (e.g., Grönroos, 2003; Kingman-Brandage, 1989; Pires, Stanton and Stanton, 2004; Sawhney et al., 2004). The objective is to identify co-creation opportunities including: highlighting points of service failure; identifying processes for service recovery; improving the encounter experience; and, where necessary, re-engineering processes.

CCC uses the online and mobile channels innovatively, for co-creation at several points during the encounter process. For example, the car booking system operates through mobile channels as well as online. These are both efficient, cost effective channels for CCC, and customers can access them conveniently. The system gives instant information on car availability, optimising use of the car fleet 
and giving customers immediate information on car choice. A further enhancement has recently been added, with an SMS service informing the customer when the previous user returns their reserved car. The elegance of the CCC concept lies in the simplicity the company has engineered into many operations, the sophistication of information technology systems, and the organisation's ability to change or upgrade processes.

\section{Designing specific encounters}

The mapping activity described above provides the structure for the next step of designing a specific encounter that supports the brand co-creation opportunity. Figure 5 illustrates this process for CCC. In this example, the encounter of opening the car doors is analysed to identifying how co-creation can be optimised. The process includes identifying: the goal of the encounter (successful pick-up of the car); ensuring the CCC branding is visible (e.g., prominent use of the logo on the car windscreen and in identifying the parking space); content (customer dials into automated system and, using a pin, accesses the car - the doors open automatically); input (system updates car reservation); output (system updates car information at the start of rental period); channel (mobile phone); service-scape (parking area tidiness, etc.); a 'catch' or special feature that creates positive customer emotions (the amazement of the customer at the automatic opening of car doors); and responsibility (identify the functional area of the organisation responsible for encounter activity).

\section{FIGURE 5 HERE}

Designing a specific encounter, such as this procedure for opening the doors, involves considerable innovation. The importance of this encounter lies in providing an opportunity that is likely to delight and differentiate the customer experience. In this example, the customer accesses the central locking system of the car on a mobile phone, using a designated unique number, and the doors of the car open by themselves. This experience surprises and amuses customers using the service for the first time. The 
encounter is one that they will often recount to others. This experience represents the fun component of experiental brands (Holbrook and Hirschann, 1982). The car keys are located in the glove box and the customer is now ready to enjoy their car hire experience. For example, a customer describes this experience in a blog as follows: "They have parking areas all around the capital area, mostly concentrated on areas with high population density. The keys are left in the car, and you can open the car with your cell phone, no problem there!"

\section{Additional influences on the brand experience}

CCC has chosen to position itself as a "Club" and calls customers "members". The membership creates emotional bonds (Liljander and Strandvik, 1995) with, and amongst the customers. CCC encourages members to share their experiences of the brand in order to build a sense of community amongst members. Members can learn about other opportunities for brand enhancement, which may influence their brand experience and enhance value. For example, the web site offers information about other members of the community and identifies the profile of various customers, including how each one uses the membership services. Members can browse these and learn how others in the community enjoy the service, adding to their own experience. The web site also provides examples of typical cost savings for members, profiled by typical car usage patterns.

CCC encourages members to participate in a 'Car-Free-Day', a Finnish Government initiative aimed at encouraging responsible transportation decisions. This initiative helps build a sense of community around environmentally responsible social behavior. A shared sense of moral responsibility and participative experiences help define these communities and social networks (Achrol and Kotler, 2006). In addition, the CCC web site lists business members, with links given to each company's web site. This list of business members, benefits both the club (through member endorsement) and individual business members (through promotion of their business). 
$\mathrm{CCC}$ reports a number of practical co-creation consequences resulting from customers viewing themselves as members. First, customers generally treat the cars with considerable care. They experience "car ownership" and, hence, customers drive the cars more carefully and return them cleaner than a typical rental car. Members also typically leave the petrol tank at least a quarter full. Often members use the same car, parked in the same parking place on many subsequent occasions. They quickly realize that neighborhood members reciprocate with considerate treatment of the car.

Second, the members are involved in co-creation by providing valuable feedback to CCC. The company has two main feedback systems and they have designed encounters for this purpose.

Spontaneous feedback is encouraged on the website, and CCC reports that most of this feedback is very constructive. The feedback typically relates to the improvement of the service process. CCC records this data into a "development tree", which is structured around internal processes. CCC uses this member feedback as an input for the continuous development of service processes and procedures. A further type of feedback is a survey that CCC conducts every year. This survey not only measures customer satisfaction, but also aims at understanding the actual behavior of different member groups. The survey is web-based and over $40 \%$ of the members respond, providing CCC with very valuable insights about members' requirements. This survey identifies how a member uses the car, where they want to pick it up, their destination and the type of car they need. The survey information is cross-tabulated with actual transaction data and creates a basis for organizational learning.

Third, CCC sometimes offers the most frequent users certain services (such as travel packages, tickets to concert, etc.) at favorable prices through a third party. Members taking up such offers can meet and interact with each other without any additional effort by CCC. During these events, members share their experiences with each other, and with non-members, thus reinforcing their brand community experience and at the same time performing the job of "part-time marketers". 
Another important influence on the brand experience is the impact of social trends. Some people may regard car ownership as a status symbol and an extension of their personality because of a car's visibility and association with affluence. However, as fashion trends move towards simplicity in lifestyle, ownership of expensive cars is less appealing. Also, lobby groups are putting pressures on government to make car use more difficult and expensive. A recent customer suggests that by joining the car club: "You will be able to bask in the admiration of your friends and neighbours, not just for being so clever, but for doing your bit to save the planet".

\section{Findings from the case study}

The case illustrates the process of co-creating a brand by designing and managing the relationship experience. The authors identify three relationship phases, each with distinctive objectives. Identifying specific aims help CCC design co-creation opportunities appropriate to each relationship phase, including specific encounters where customer and supplier processes meet. Critically, the case identifies the importance of additional sources of brand knowledge, which influence the value created by the brand relationship. In this example, environmental concerns create empathy amongst users and willingness to participate in a self-serve relationship experience.

In summary, the CCC case illustrates an innovative service that capitalizes on opportunities for co-creation and provides Club members of its community with a flexible solution to the practical and environmental problems of car ownership at a lower cost than traditional car rental. Positioning the brand as a Club allows CCC to engage with customers in co-creation. $\mathrm{CCC}$ supports this co-creation in a systematic way where customers can learn to use the service more effectively and, in turn, CCC learns from Club members how to better support them. Several opportunities make co-creation possible, including an innovative combination of new technology and a successful alignment with other stakeholders who provide resources supporting the relationship. These other stakeholders include 
municipalities (parking spaces), car manufacturers (low-emission cars), technology providers (such as telecommunications companies), and third party vendors (value-adding components).

\section{Summary and Discussion}

Many researchers point to the need for more work in the area of co-creation, relationships, customer experience and branding. Keller and Lehmann (2006) highlight brand relationships and customer experience as key areas requiring further development. Schroeder and Salzer-Mörling (2006) emphasize that understanding brands "requires integrative thinking, drawing from management strategy, organization theory, and consumer behaviour, and that understanding brands requires theoretical work". This current study represents a step in this direction by integrating such literatures into a conceptual model for designing and planning the customer experience involved in co-creating brands.

This article examines the co-creation of value in the context of service-dominant logic, proposes a conceptual model of co-creation for managing brand relationship experiences and develops a case study about an innovative service which utilizes opportunities for co-creation that reflect changing consumer preferences and new developments in mobile technology. The article makes a theoretical and practical contribution to the emerging literature on the brand relationship experience.

The article's theoretical contribution is in developing and refining a model for understanding the brand relationship experience in the context of service-dominant logic. The traditional informationprocessing stream of consumer research emphasizes cognition, affect and behavior in a narrow sense. Researchers need also to consider a broader context when exploring the brand relationship experience. Holbrook and Hirschman (1982) conclude that while an information processing approach explains much of buyer behavior, an experiential perspective of encounters can often be greatly enriching. The article categorizes encounters based on the opportunity to support co-creative processes as emotion-supporting 
encounters, cognition-supporting encounters and action-supporting encounters, and proposes that management needs to understand how to design such encounters to enable the co-creation of brands.

The article makes a practical contribution through the development of a case study illustrating the application of the co-creation model. The case research explores the building of brand experiences by setting goals for both customer and supplier at each relationship phase; mapping the types of encounters and determining which channels are most appropriate for different customer segments; and developing a detailed process outline for managing each individual encounter.

Von Krogh and Roos (1996) argue that success in the field of management hinges on an ability to develop concepts that are useful to managers. The conceptual approach discussed in this article has been developed and tested with senior executives in several companies as part of an interactive research process. These managers judged the model to be a practical and useful tool in helping them co-create the brand relationship experience with their customers. In addition, some companies are using the model for assisting the training of employees involved in the design and delivery of experiential service encounters. The authors have also undertaken some preliminary work in seeking out the views of consumers as to the relevance of the model for co-creation. Focus group research among eighteen potential consumers of the CCC revealed that, when briefed on the model, group members were able to generate a greater number of opportunities for co-creation than when they considered co-creation opportunities in the absence of such a stimulus. These potential consumers were enthusiastic about the value of the model and how its components helped them identify opportunities for co-creation.

As with most research, the study has limitations, which point to future research opportunities. First, the current research relating to the brand experience has, as its major focus, the business-to consumer sector. The business-to-business sector requires further research as the decision making process will add complexity to the value creation process. Second, the case research reported here focuses on just one 
organization in the business-to-consumer sector. Further case studies applying the co-creation model to other business-to-consumer organizations represent an opportunity for future work. Third, the study only incorporates a small focus group of customers. Future opportunities exist in involving consumers more extensively in such research.

The case study also raises interesting research possibilities with respect to aligning brands more closely with sustainability and environmental cause-related issues. Gordon (2002) observes, "We are drawn to brands we trust, brands that are different from the rest, brands that are innovative, brands that appeal to the emotions." Investigations of brands that appeal strongly to the growing demand for goods and services that are sustainable and reduce owners' emotional and financial costs warrant special research attention.

Despite a considerable number of contributions to the service-dominant logic debate, including specific work on co-creation, there remain significant opportunities to research customer experiences and how they can contribute to understanding brand management in a service-dominant environment. Although the application of service-dominant logic to branding is at an early stage of development, the authors suggest the topic shows much promise as a research area and concur with Prahalad's (2004) view of the co-creation perspective where the brand becomes the experience. 
Figure 1: Overview of Model Development Process

\begin{tabular}{|c|c|c|c|c|c|}
\hline \multicolumn{2}{|l|}{ Phase 1: Pre-understanding } & \multicolumn{2}{|l|}{ Phase 2: Analysis } & \multicolumn{2}{|c|}{ Phase 3: Model development } \\
\hline $\begin{array}{l}\text { - Literature identification \& } \\
\text { secondary data collection } \\
\text { - Planning research } \\
\text { methodology } \\
\text { - Expert interviews and } \\
\text { identification of case } \\
\text { companies } \\
\text { - Company interviews in } \\
\text { USA and Europe }\end{array}$ & 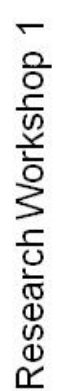 & $\begin{array}{l}\text { - Research Workshop } 1 \\
\text { input to approach and } \\
\text { priorities } \\
\text { - Literature review \& } \\
\text { analysis of secondary } \\
\text { data } \\
\text { - Description and writing } \\
\text { up of company materials } \\
\text { - Preliminary development } \\
\text { of model components }\end{array}$ & 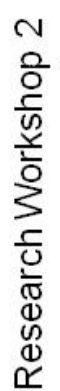 & $\begin{array}{l}\text { - Synthesis of Research } \\
\text { Workshop } 2 \text { output } \\
\text { - Analysis of key themes } \\
\text { and best practices } \\
\text { - Development of model } \\
\text { - Extension of literature } \\
\text { review based on model } \\
\text { development } \\
\text { - Model refinement and } \\
\text { testing }\end{array}$ & 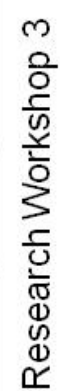 \\
\hline
\end{tabular}

Figure 2: A model for Co-Creating the Brand Relationship Experience

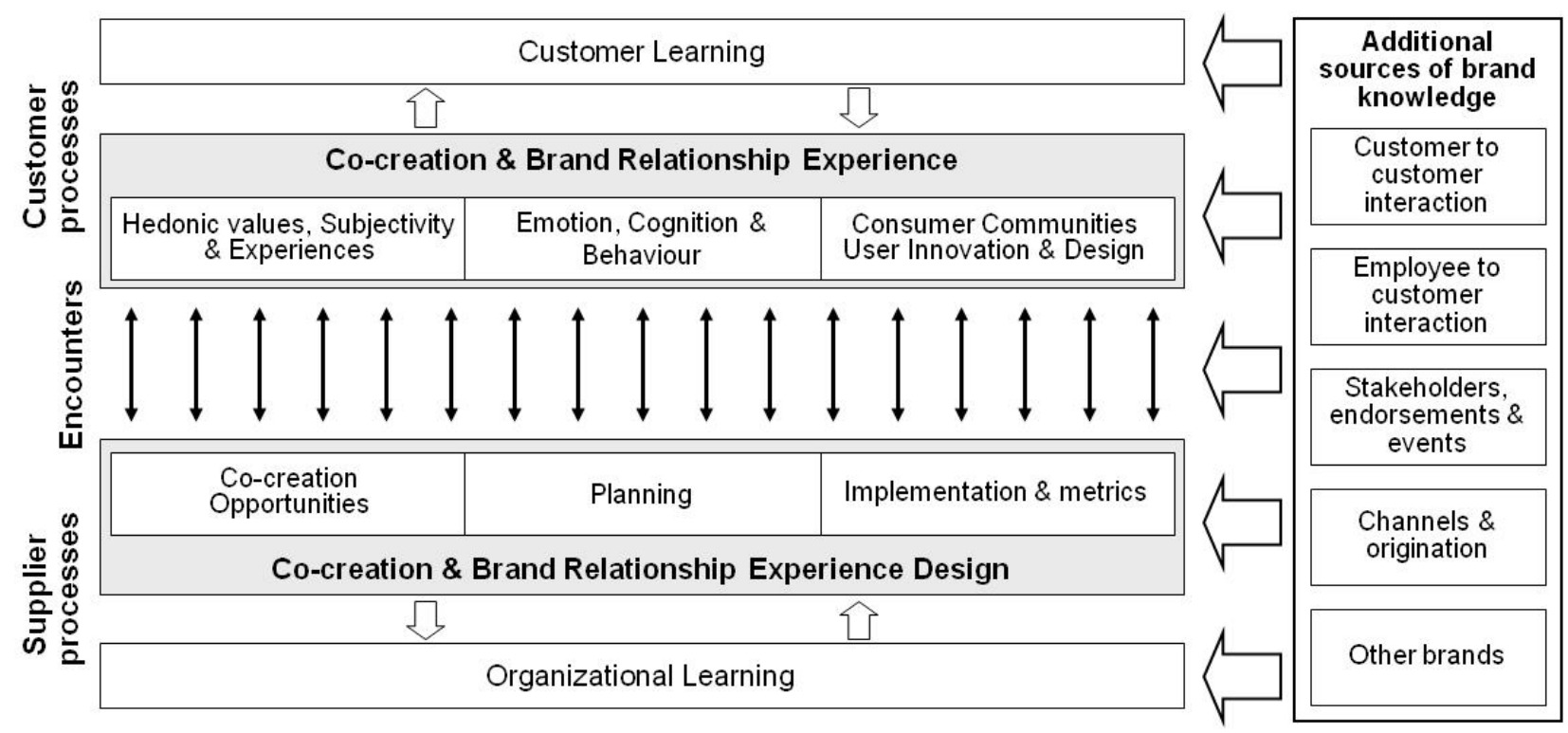


Figure 3: City Car Club: Objectives for Relationship Phases

\begin{tabular}{|c|c|c|c|}
\hline & \multicolumn{3}{|c|}{ Relationship Phase } \\
\hline & Acquisition & Stabilization & Enhancement \\
\hline $\begin{array}{l}\text { The Club } \\
\text { member has: }\end{array}$ & $\begin{array}{l}\text { - become convinced that } \\
\text { memberships is valuable } \\
\text { - been positively surprised } \\
\text { to find out about the car } \\
\text { sharing concept } \\
\text { registered as a new } \\
\text { member }\end{array}$ & $\begin{array}{l}\text { - learned the basic ways to } \\
\text { use the service } \\
\text { - become aware of his own } \\
\text { and the club's } \\
\text { responsibilities } \\
\text { - paid his monthly bill on } \\
\text { time } \\
\text { - used the services more } \\
\text { than once }\end{array}$ & $\begin{array}{l}\text { - started to use the } \\
\text { services on a regular } \\
\text { basis } \\
\text { - learned to book a car on } \\
\text { the web site } \\
\text { - recommended the Club } \\
\text { to someone }\end{array}$ \\
\hline $\begin{array}{l}\text { The Club } \\
\text { has: }\end{array}$ & $\begin{array}{l}\text { - acquired a new member } \\
\text { (customer) } \\
\text { - accurate data on the } \\
\text { member } \\
\text { - information on how the } \\
\text { customer found out } \\
\text { about the club }\end{array}$ & $\begin{array}{l}\text { - started to generate } \\
\text { revenue from the } \\
\text { customer } \\
\text { - encouraged the use of the } \\
\text { Club's services } \\
\text { - created an initial service } \\
\text { usage profile of the } \\
\text { member }\end{array}$ & $\begin{array}{l}\text { - started to generate } \\
\text { steady revenue (a loyal } \\
\text { customer) } \\
\text { - enhanced the usage } \\
\text { profile of the member } \\
\text { - engaged the customer in } \\
\text { interaction with the Club } \\
\text { for further development }\end{array}$ \\
\hline
\end{tabular}

Figure 4: City Car Club: Relationship Encounter Design

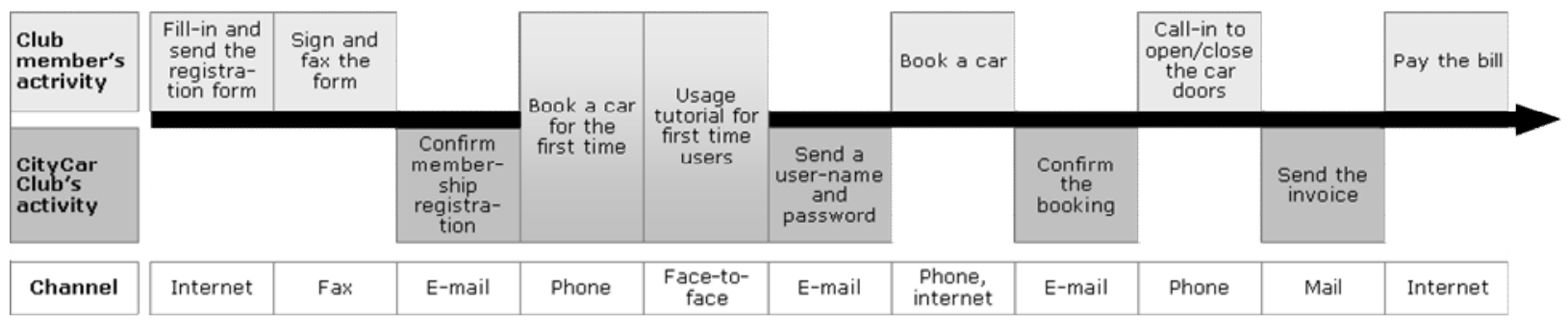


Figure 5: City Car Club: Designing a Specific Encounter

\begin{tabular}{|c|c|}
\hline \multicolumn{2}{|r|}{ OPENING THE CAR DOORS } \\
\hline Goal & Customer picks-up the car successfully. \\
\hline Brand visibilty & $\begin{array}{l}\text { Sticker on the car with the club logo, speech on automatic answer service, } \\
\text { sign at parking space }\end{array}$ \\
\hline Content & $\begin{array}{l}\text { Customer calls } 02008811 \text {, the automatic answer service greets him and } \\
\text { gives directions. The customer keys in his PIN code and the last three } \\
\text { numbers of the car's registration plate. The car doors open within seconds. }\end{array}$ \\
\hline Input & Data on customer's reservation (date, time, pick-up location) \\
\hline Output & The start-time of the car usage, which is needed to calculate the usage fee. \\
\hline Channel & Mobile phone, parking space \\
\hline Service-scape & Street, parking space, car (type, tidiness, age, size etc.) \\
\hline Catch & $\begin{array}{l}\text { Positive feelings raised by the amazement of seeing the car doors opening } \\
\text { "by themselves". } \\
\text { The call initiates the usage fee "calculator" which stops by returning the car. }\end{array}$ \\
\hline Responsibility & Which part of the organization is responsible for the encounter? \\
\hline
\end{tabular}




\section{References}

Achrol R, Kotler P. The service-dominant logic for marketing: a critique. In: Lusch R F, Vargo S L, editors. The service dominant logic of marketing: dialog, debate and directions. Armonk, New York: M.E. Sharpe, 2006. pp. 224-235.

Aggarwal P. The effects of brand relationship norms on consumer attitudes and behavior. Journal of Consumer Research 2004; 31 (1): 87 -101.

Ambler T. The new dominant logic of marketing: views of the elephant. Centre for Marketing. 2004; Working Paper No. 04-903: London Business School (November).

Arnould E J, Price L L, Malshe A. Toward a cultural resource-based theory of the customer. In: Lusch R F, Vargo S L, editors. The service dominant logic of marketing: dialog, debate and directions, Armonk, New York: M.E. Sharpe, 2006. pp. 91-104.

Ballantyne D, Varey R J. Introducing a dialogical orientation to the service-dominant logic of marketing. In: Lusch R F, Vargo S L, editors. The service dominant logic of marketing: dialog, debate and directions, Armonk, New York: M.E. Sharpe, 2006. pp. 224-235. Balmer J M T. Corporate brand cultures and communities. In: Schroeder J E, Salzer-Mörling M, editors. Brand Culture. London: Routledge, 2006. pp. 35-49.

Balmer J M T, Gray E R. Corporate brands: what are they? What of them? European Journal of Marketing 2003; 37 (7-8): 972-997.

Bello R, de Chernatony L, Shiu E. Consumer-brand relationships: a tetrad classification. Paper presented at Thought Leaders International Conference on Brand Management, Birmingham Business School 2007; (April).

Bendapudi N, Leone R P. Psychological implications of customer participation in co-production. Journal of Marketing 2003; 67 (January): 14-28. 
Bennett A. Subcultures or neo-tribes? Rethinking the relationship between youth, style and musical taste. Sociology 1999; 23 (3): 599-617.

Blomqvist K, Posmer S. Three strategies for integrating CSR with brand marketing. Market Leader 2004; (Summer): 33-36.

Brodie R J, Glynn M S, Little V. The service brand and the service-dominant logic: missing fundamental premise or the need for stronger theory? Marketing Theory 2006; 6 (3): 363-379.

Brooks R, Lings I. A hierarchy of customer satisfaction, the inadequacies of service blueprinting In: Beracs J, Simon J, editors. Marketing for an Expanding Europe, Vol II, Proceedings of the $25^{\text {th }}$ Annual Conference of the European Marketing Academy, Budapest, Hungary; 1996. pp. 147-64.

Brown S W, Fisk R P, Bitner M J. The development and emergence of services marketing thought. International Journal of Service Industry Management 1994; 5 (1): 21-48.

Charter M, Peattie K, Ottman, Polonsky J. Marketing and sustainability. Sustainable Marketing Knowledge Network. London, 2002.

Cova B. Community and consumption. Towards a definition of the "linking value" of product or services. European Journal of Marketing 1997, 31 (3-4): 297-316.

Cova B, Cova V. Tribal marketing: the tribalisation of society and its impact on the conduct of marketing. European Journal of Marketing 2002; 36 (5-6): 595-620.

Cova B, Kozinets R, Shankar A. Consumer tribes. Amsterdam, NY: Butterworth-Heinemann; 2007.

Csaba F F, Bengtsson A. Rethinking identity in brand management. In: Schroeder J E, Salzer-Mörling M, editors. Brand culture. London: Routledge, 2006.

Dall'Olmo Riley F, de Chernatony L. The service brand as a relationship builder. British Journal of Management 2000; 11 (2): 137-50. 
de Chernatony, L. From brand vision to brand evaluation: the strategic process of growing and strengthening brands. Oxford: Butterworth Heinemann, 2006.

de Chernatony L, Harris F. Developing corporate brands through considering internal and external stakeholders. Corporate Reputation Review 2000; 3 (3): 268-274.

Demirbilek O, Sener B. Product design, semantics and emotional response. Ergonomics 2003; 46 (1314): $1346-1360$.

Dowling G. Customer relationship management: in B2C markets, often less is more. California Management Review 2002; 44 (3): 87-104.

Eisenhardt K M. Building theories from case study research. Academy of Management Review 1989; 14 (4): 532-550.

Edvardsson B, Enquist B, Johnston R. Co-creating customer value through hyperreality in the prepurchase service experience. Journal of Service Research 2005; 8 (2): 149-161.

Fournier S M. Consumers and their brands: developing relationship theory in consumer research. Journal of Consumer Research 1998; 24 (March): 343-373.

Füller J, Jawecki G, Mühlbacher H. Innovation creation by online basketball communities. Journal of Business Research 2007; 60: 60-71.

Glasser B, Strauss A. The discovery of grounded theory: strategies of qualitative research, London: Wiedenfeld and Nicholson, 1967.

Gordon W. Brand green: mainstream or forever niche?; London UK: Green Alliance 2002.

Goulding G, Saren M. 'Gothic' entrepreneurs: a study of the subcultural commodification process. In: Cova B, Kozinets R V, Shankar A, editors. Consumer tribes. Oxford: Elsevier Butterworth Heinemann, 2007, pp. 227-242. 
Gremler D D. The critical incident technique in service research. Journal of Service Research 2004; 7 (1): 65-89.

Grönroos C. Adopting a service logic for marketing. Marketing Theory 2006; 6 (3): 317-333.

Grönroos C. Service management and marketing. second edition, Chichester, England: Wiley, 2003.

Grönroos C. Service management and marketing: managing the moment of truth in service competition. Lexington, Massachusetts: Lexington Books, 2000.

Grönroos C. Value-driven relational marketing: from products to resources and competencies. Journal of Marketing Management 1997; 13 (July): 407-419.

Gummesson E. Practical value of adequate marketing management theory. European Journal of Marketing 2002; 36 (March): 325-49.

Gummesson E. Relationship marketing as a paradigm shift: some conclusions from the 30R approach. Management Decision 1997; 5 (4): 267-272.

Holbrook M B. The consumption experience - something new, something old, something borrowed, something sold: Part 1. Journal of Macromarketing 2006a; 26 (2): 259-266.

Holbrook M B. The consumption experience - something new, something old, something borrowed, something sold: Part 2. Journal of Macromarketing 2006b; 27 (1): 86-96.

Holbrook M B. The consumption experience - something new, something old, something borrowed, something sold: Part 3. Journal of Macromarketing 2007a; 27 (2): 173-201.

Holbrook M B. The consumption experience - something new, something old, something borrowed, something sold: Part 4. Journal of Macromarketing 2007b; 27 (3): 173-201.

Holbrook M B, Hirschman E C. The experiential aspects of consumption: consumer fantasies, feelings, and fun. Journal of Consumer Research 1982; 9 (September): 132-40. 
Jevons C. Towards an integrated definition of "brand". Paper presented at Thought Leaders International Conference on Brand Management, Birmingham Business School, 2007; (April). Kamali M, Loker S. Mass customization: on-line consumer involvement in product design. Journal of Computer-Mediated Communication 2002; 7 (4): Retrieved October 22, 2007 from http://jcmc.indiana.edu/vol7/issue4/loker.html

Keller K L. Brand synthesis: the multidimensionality of brand knowledge. Journal of Consumer Research 2003; 29 (March):595- 600.

Keller K L, Lehmann D R. Brands and branding: research findings and future priorities. Marketing Science 2006; 25 (6): 740-739.

Kingman-Brundage J. The abcs of service system blueprinting. In: Bitner M J, Crosby L A, editors. Designing a winning service strategy. American Marketing Association Proceedings Series. Chicago, Il: American Marketing Association, 1989, pp. 30-3.

Knox S, Maklan S. Corporate social responsibility: moving beyond investment towards measured outcomes. European Management Journal 2004; 22 (5): 508-515.

Korkman O. Customer value formation in practice: a practice-theoretical approach. Series A: 155, Helsinki: Swedish School of Economics and Business Administration, 2006.

Kozinets R. E-tribalized marketing? The strategic implications of virtual communities of consumption. European Management Journal 1999; 17 (3): 252-264.

Liljander V, Strandvik T. The nature of customer relationships in services. In: Swartz T A, Bowen, D E, Brown S W, editors. Advances in Services Marketing and Management 4, London: JAI Press, 1995, pp.141-167.

Loose W, Mohr M, Nobis C. Assessment of the future development of car sharing in Germany and related opportunities. Transport Reviews 2006; 26 (3): 365-382. 
McAlexander J H, Schouten J W, Koenig H F. Building brand community. Journal of Marketing 2002; 66 (1): 38-54.

McConnell B, Huba J. Citizen marketers: when people are the message. Chicago: Kaplan Publishing, 2007.

Muniz A M, O’Guinn T C. Brand Community. Journal of Consumer Research 2001; 27 (4): 412-32.

Normann R. Reframing business: when the map changes the landscape. Chichester, England: John Wiley \& Sons Ltd, 2001.

Normann R, Ramirez R. From value chain to value constellation. Harvard Business Review 1993; (JulyAugust): 65-77.

Oliver R L. Value as excellence in consumption experience. In: Holbrook M B, editor. Consumer value: a framework for analysis and research. London and New York: Routledge, 1999, pp. 43-62.

O’Malley L, Tynan C. Reframing relationship marketing for consumer markets. Interactive Marketing $2001 ; 2$ (3) 240-6.

Patterson M. Direct marketing in postmodernity: neo-tribes and direct communications. Marketing Intelligence and Planning 1998; 16 (1): 68-74.

Payne A, Storbacka K, Frow P. Managing the co-creation of value, working paper, Cranfield School of Management, 2008.

Pine B J. Mass customization. Boston, MA: Harvard Business School Press, 1993

Pine B J, Gilmore J H. The experience economy: work is theatre and every business a stage. Boston, MA: Harvard Business School Press, 1999.

Pires G, Stanton P, Stanton J. The role of customer experiences in the development of service blueprints. Australia and New Zealand Marketing Academy Proceedings, 2004.

Prahalad C K. The co-creation of value. Journal of Marketing 2004; 68 (1): 23. 
Prahalad C K, Ramaswamy V. Co-opting customer competence. Harvard Business Review 2000; 78 (January): 79-90.

Prahalad C K, Ramaswamy V. The Future of competition: creating unique value with customers. Boston, MA: Harvard Business School Press, 2004.

Reichheld F. The loyalty effect. Boston, MA: Harvard Business School Press, 1996.

Rozanski H D, Baum A G, Wolfsen B T. Brand zealots: realizing the full value of emotional brand loyalty. Strategy and Business 1999; 17 (Fourth Quarter): 51-62.

Sawhney M. Going beyond the product: defining, designing, and delivering customer solutions. In: Lusch R F, Vargo S L, editors. The service dominant logic of marketing: dialog, debate and directions, Armonk, New York: M.E. Sharpe, 2006, pp.365 -380.

Sawhney M, Balasubramanian S, Krishnan V. Creating growth with services. MIT Sloan Management Review 2004; 45 (Winter): 34-43.

Schroeder J E, Salzer-Mörling M, editors. Brand culture. London: Routledge, 2006.

Schultz M, and Hatch M J. A cultural perspective on corporate branding. In Schroeder J E, SalzerMörling M, editors. Brand culture. London: Routledge, 2006, pp.15-33.

Sheth J N. Relationship marketing: paradigm shift or shaft? Paper presented at the Annual Meeting of the Academy of Marketing Science 1996, Miami, FL.

Shostack G L. Designing services that deliver. Harvard Business Review 1984; (January-February):133139.

Smit E, Bronner F, Tolboom M. Brand relationship quality and its value for personal contact. Journal of Business Research 2007; 60: 627-633. 
Srivastava R K, Shervani T A, Fahey L. Marketing, business processes and shareholder value: an organizationally embedded view of marketing activities and the discipline of marketing. Journal of Marketing 1999; 63: 168-179.

Storbacka K, Lehtinen J R. Customer relationship management: creating competitive advantage through win-win relationship strategies. Singapore: McGraw-Hill Book Co, 2001.

Swaminathan V, Page K L, Gurhan-Canli Z. My brand or our brand: the affects of brand relationship dimensions and self construal on brand evaluation. Journal of Consumer Research 2007; 34 (2): 248-259.

Tapscott D, Williams A D. Wikinomics: how mass collaboration changes everything. London: Portfolio, 2006.

Thompson L, Fine G A. Socially shared cognition, affect and behavior: a review and integration. Personality and Social Psychology Review 1999; 3 (4): 278-302.

Urban G L, Von Hippel E. Lead user analysis for the development of new industrial products. Management Science 1988; 34 (5): 569-582.

Van Heel O D, Elkington J, Fennel S. Buried treasure: uncovering the business case for corporate sustainability: London UK: Sustainability, 2001.

Vargo S L, Lusch R F. Evolving to a new dominant logic for marketing. Journal of Marketing 2004; 68 (1): 1-17.

Vargo S L, Lusch R F. Service-dominant logic: continuing the evolution. Journal of the Academy of Marketing Science 2008 (forthcoming).

Vargo S, Morgan F W. Services in society and academic thought: an historical analysis. Journal of Macromarketing 2005; 25 (1): 42-53. 
Von Hippel E. Lead users: a source of novel product concepts. Management Science 1986; 32 (7): 791798.

Von Krogh G, Roos J. A tale of the unfinished. Strategic Management Journal 1996; 17: 729-737.

Webster F E Jr. Marketing management in changing times. Marketing Management 2002; 11 (January/February): 1-17.

Wallendorf M, Belk R W. Assessing trustworthiness in naturalistic consumer research. In: Hirschman E, editor. Interpretive consumer research. New Jersey: Association for Consumer Research, 1989. 